\title{
Erizaina eta komunikazioa egoera terminalean dauden gaixo pediatrikoekin eta horien familiekin
}

\author{
Nurse and communication with terminal pediatric patients and their families
}

\author{
Aiora Mayoz Elicegui ${ }^{1,2}$ \\ ${ }^{1}$ Erizaintza II Saila, Medikuntza eta Erizaintza Fakultatea, UPV-EHU, \\ ${ }^{2}$ Donostia Unibertsitate Ospitalea \\ aioramayoz@gmail.com
}

\section{Laburpena}

Gaurko gizartean, haurtzaroa eta nerabezaroa poztasun- eta zoriontasun-garai moduan identifikatu arren, aldi horretan zenbait gaixotasun agertzea ohikoa izaten da eta haurren zein nerabeen heriotza ere errealitate bat da. Hala ere, azken urteetan, gaixotasun sendaezinak dituzten haurren eta nerabeen biziraupena luzatzen joan da, eta, ondorioz, zainketa aringarri pediatrikoak geroz eta indar handiagoa hartzen joan dira. Zainketa horietan, beste gauza batzuen artean, komunikazioa funtsezko tresna bilakatzen da. Komunikazioa, esfortzua, ardura eta abilezia eskatzen duen alor bat da eta kasu askotan informatzearekin erlazionatzen den arren, hori baino haratago doan prozesua da. Lan honen helburua egoera terminalean dauden gaixo pediatrikoekin eta horien familiekin erizainak izan beharreko komunikazioa deskribatzea da. Literaturaren berrikuspen narratiboa egin da, gako-hitz eta deskriptore desberdinetan oinarrituz Biblioteca Virtual de la Salud (BVS), PubMed, Medes eta Dialnet datu-baseetan bilaketak eginez. Horretaz gain, hainbat web-orri eta liburu kontsultatu eta bigarren mailako bilaketa burutu da. Gaixo pediatrikoetan, komunikazioaren egokitzapenak duen garrantzia eta horren nondik norakoak azaldu dira. Bestalde, egoera terminalean dauden haur eta nerabeekin komunikatzeko, osasun-profesionalak garatu beharreko komunikazio-teknikak landu dira. Jarraian, heriotzaren inguruko elkarrizketa egiteko kontuan izan beharreko puntuak deskribatu dira. Azkenik, osasun-profesionalen eta familiaren arteko komunikazioa azaldu da. Ondorio nagusi moduan zera esan daiteke: zainketa aringarri pediatrikoetan komunikazioa funtsezko tresna den arren, praktikan gabezia ugari nabari diren alorra dela.

Gako-hitzak: Zainketa aringarriak, gaixo terminalak, pediatria, erizaina, komunikazioa

\section{Abstract}

Although childhood and teenagers' times are usually synonymous with happiness in today's society, the emergence of some illnesses is quite normal and so the death of children and teenagers is a sad fact. However, in recent years, the lifespan of incurable children and teenagers has grown and consequently palliative pediatric care has become increasingly more widespread. During that care, communication becomes an important element among many other things. Communication is a field that requires effort, care and ability and although it is often related to informing, it is a process that goes beyond communication. The aim of this project is to describe the communication that a nurse needs to have with terminal pediatric patients and their families. Narrative literature review, based on key words and different descriptors, has been made by carrying out data based research in Biblioteca Virtual de la Salud (BVS), PubMed, Medes and Dialnet. Besides, many websites and books 
as well as second level research have been consulted.The importance of appropriate communication and its place have been presented. Apart from that, communication techniques that health professionals have to develop with terminally ill children and teenagers have been analysed. Next, what you need to take into consideration when holding an interview about death has been explained. Finally, communication between family and health professionals has been described.As a consequence, it should be mentioned that even though communication is an essential instrument in terminal pediatric care, several shortcomings still exist in practice.

Keywords: Palliative care, terminally ill, pediatrics, nursing, communication.

Bidalia: 2019ko abuztuaren 6an.

Onartua: 2019ko azaroaren 4an.

http://doi.org/10.26876/osagaiz.2.2019.273

\section{Sarrera}

Gaurko gizartean, haurtzaroa eta nerabezaroa poztasun- eta zoriontasun-garai moduan identifikatu arren, aldi horretan zenbait gaixotasun agertzea ohikoa izaten da. Gaixotasun gehienak arinak izan ohi diren arren, haur batzuek gaixotasun larri eta iraupen luzekoak pairatzen dituzte. Horietako kasu batzuetan, tratamendu espezifikoek eraginkortasuna galdu eta horrekin batera sendatzeko esperantza galtzen da. Gaixotasunaren fase terminalari hasiera eman eta heriotza gertu ikusten da (1).

Gaixo bat egoera terminalean dagoela esaten da, gaixotasun aurreratu, progresibo eta sendaezin bat duenean, bizi-prognosi mugatuarekin (normalean $<6$ hilabete). Gaixo terminalek askotariko sintomak, biziak eta aldakorrak pairatzen dituzte, eta sintoma horiek inpaktu emozional handia eragiten dute gaixoarengan, familiarengan eta baita osasun-profesionalengan ere (1-4).

Haurren eta nerabeen heriotza errealitate bat den arren, gizarteak orokorrean ez du espero haur bat hiltzerik eta ez dugu behar adina prestakuntza horrelako egoera bati aurre egiteko $(2,5)$.

Espainiaren kasuan, urtean 3.000 haur inguru hiltzen dira (5). Aipatzekoa da, medikuntzako aurrerapenek gaixo pediatrikoen heriotza-tasaren jaitsiera eragin badute ere, gaixotasun sendaezinak dituzten haurren eta nerabeen biziraupena luzatzea ekarri dutela $(6,7)$. Horren aurrean, zainketa aringarri pediatrikoak geroz eta paper garrantzitsuagoa hartzen joan dira azken urteetan (6).

Osasunaren Mundu Erakundearen (OME) arabera, zainketa aringarri pediatrikoak haurraren eta bere familiaren bizi-kalitatea hobetzea helburu duten zainketa integral eta aktiboak dira $(2,6)$. Zainketa integral moduan definitzen dira, gaixoaren behar guztiak osotasunean hartuz eskainiriko zainketak. Gaixoaren alor fisiko edo biologikoaz gain, alderdi psikoemozionala, soziala eta espirituala ere kontuan hartuz eskainiriko zainketak hain zuzen $(3,8)$. Bertan, diziplina anitzeko profesionalen arteko elkarlana ezinbestekoa da (8). Bestalde, zainketa aktiboak direla esaten da, osasun-profesionalen aldetik, "ez dago ezer gehiago egiterik" pentsatzeari utzi eta jarrera gogotsuarekin, aurrez ezarritako helburuen arabera eta gaixo bakoitzaren egoerara egokituz eskainitako zainketak direlako (3).

OMEren esanetan, zainketa aringarriak gaixotasunaren diagnostikoarekin hasten dira eta gaixotasunaren prozesu osoan zehar jarraitzen dute. Ospitalean, osasun-zentroan edota haurraren etxean egin daitezke eta zainketa aringarri eraginkorrak egiteko, diziplina anitzeko abordatzea ezinbestekoa dela aipatzen du. Gainera, eskura dauden baliabideak erabili eta familiari ere behar dituen zainketak eskaintzea funtsezkoa dela zehazten du. $(2,6)$.

Haur eta nerabe bakoitzak gaixotasunaren eta heriotzaren aurrean psikologikoki egokitzeko prozesuan, erreakzio desberdinak azaleratzen ditu adinaren, garapen kognitiboaren edota aurrez gaixotasunekin eta heriotzarekin bizi izandako esperientzien arabera. Osasun-profesionalei dagokienez, garrantzitsua izango da gaixoaren erreakzioak identifikatzeko gaitasuna izatea $(9,10)$. 
Prozesu horretan, osasun-profesionalaren eta gaixoaren artean komunikazio egokia mantentzea ezinbesteko tresna bilakatzen da (9).

Osasun-alorrean, esfortzua, ardura eta abilezia eskatzen duen alorra da komunikazioa (11). Kasu askotan, pertsona batekin komunikatzea, zerbaiten inguruan informatzearekin erlazionatzen den arren, esan beharra dago, komunikazioa informatzea baino haratago doan terminoa dela. Komunikazioa prozesu bat da, non pertsonak sentimenduak, zalantzak, beldurrak, itxaropenak eta egonezinak konpartitzen dituen ahozko eta ez-ahozko komunikazioa erabiliz (12).

Real Academia Españolaren (RAE) arabera, komunikazioa honela definitzen da (13).

- Komunikatzeko ekintza eta horren ondorioa.

- Bi pertsona edo gehiagoren arteko harremana.

- Igorleak hartzaileari, biek ezagutzen duten kodea erabiliz mezu bat bidaltzeko ekintza.

Definizio hori, osasun-alorrean aplikatu ahal izateko osatu gabe geratzen dela esan daiteke. Horren aurrean, W. Astudillok 2005. urtean honela definitu zuen komunikazio terminoa: pertsonek beren buruari eta inguruari buruzko informazioa zeinu, soinu, sinbolo edo jarrera desberdinen bidez elkarrekin trukatzea ahalbidetzen duen prozesua (11).

Zainketa aringarri pediatrikoetan, osasun-profesional guztiak komunikatzeko gaitasunean entrenatuta egotea lagungarria izango da gaixoak eta haren familiak egoerari aurre egiterako prozesuan $(11,14)$. Hala ere, pazientearekin eta senitartekoekin denbora gehien igarotzen duen profesionala erizaina dela kontuan izanik, haren komunikatzeko gaitasunak garrantzi berezia hartzen du eskainiriko zainketetan $(9,11)$.

Amaitzeko, aipatzekoa da adingabearen gurasoek edota ordezkari legalek ere eskubidea dutela haurraren edo nerabearen osasun-egoeraren inguruko informazioa jasotzeko (15). Horretaz gain, zainketa aringarri pediatrikoen definizioan aipatu bezala, gaixoaren familia ere zainketen parte bilakatzen da $(9,14)$. Gainera, pediatriako pazienteetan, kasu askotan gurasoak edota ordezkari legalak dira gaixoaren osasunaren inguruko erabakiak hartu beharko dituztenak (4). Hori horrela, osasun-profesionalak gaixoaren familiarekin behar bezalako komunikazioa mantentzea funtsezkoa izango da, kalitatezko zainketa aringarriak ziurtatzeko $(9,14)$.

\section{Helburuak}

Lan honen helburua da egoera terminalean dauden gaixo pediatrikoekin eta haien familiarekin erizainak izan beharreko komunikazioa deskribatzea. 


\section{Material eta metodoak}

Berrikuspen narratibo hau aurrera eramateko, lehenik eta behin, bilaketa bibliografikoa egiteko erabiliko ziren gako-hitzak, Descriptores en Ciencias de la Salud (DeCS) eta Medical Subject Headings (MeSH) aukeratu ziren (ikus 1. taula).

* 1. taula. Bilaketa egiteko erabili ziren gako-hitzak eta deskriptoreak. Iturria: propioa.

\begin{tabular}{|l|l|l|}
\hline \multicolumn{1}{|c|}{ Gako-hitzak } & \multicolumn{1}{|c|}{ DeCS } & \multicolumn{1}{c|}{ MeSH } \\
\hline Enfermo terminal & Enfermo terminal & Terminally ill \\
Cuidados paliativos & Cuidados paliativos & Palliative care \\
Pediatría & Pediatría & Pediatrics \\
Familia & Familia & Family \\
Enfermería & Enfermería & Nursing \\
Comunicación & Comunicación & Palliative care \\
& Intercambio de & Information \\
& información & exchange \\
\hline
\end{tabular}

Jarraian, bilaketa bibliografikoa egin zen osasun-zientzietan oinarritutako datu-base desberdinetan. Hala nola Biblioteca Virtual de la Salud (BVS), PubMed, Medes eta Dialnet. Datu-base horietan bilaketak egiteko, hautatutako ziren gako-hitzekin eta deskriptoreekin hainbat konbinazio egin ziren, AND eta OR operadore boolearrak erabiliz.

Informazio gehiago lortzeko helburuarekin, web-orri desberdinetako informazioa kontsultatu zen. Horien artean gaiarekin zuzeneko erlazioa duten zenbait erakunde eta elkarteren web-orriak aztertu ziren.

Gainera, Donostiako Medikuntza eta Erizaintzako Fakultateko liburutegian hainbat liburu kontsultatu ziren eta bilaketa sakontzeko asmoz, bigarren mailako bilaketa egin zen, lortutako artikulu eta liburuen bibliografia kontsultatuz.

Bilaketa bibliografikoa, 2018ko abendutik 2019ko otsailaren amaierara bitartean burutu zen.

\section{Emaitzak}

\subsection{Komunikazioa gaixo pediatriko terminalekin}

Zainketa aringarri pediatrikoetan, egoera terminalean dauden haurrekin eta nerabeekin jarduteko orduan, komunikazioa funtsezko tresna bilakatzen da $(1,9,12,16-20)$. Gaixoak zein haren familiak egoerari aurre egiteko orduan, osasun-profesionalek komunikazio-teknika egokiak erabiltzea lagungarri izan daiteke. Horretaz gain, bizi-kalitate eta heriotza hobea bermatzen eta dolu osasuntsua ahalbidetzen lagun dezake (16).

Osasun-profesional guztiek komunikazio-tekniketan abilezia izatea garrantzitsua den arren, erizaina izanik gaixoarekin eta haren familiarekin denbora gehien igaroko duen profesionala, haren komunikazio-gaitasunak garrantzi berezia hartzen du $(11,17,21)$. 


\subsubsection{Komunikazioaren egokitzapena}

Haur eta nerabeekin komunikatzeak baditu bere zailtasunak. Ez da gauza bera 3 urteko haur batekin, 6 urteko batekin edota 11 urteko batekin komunikatzea. Horrek hasiera batean begi-bistakoa dirudien arren, komunikazio-prozesua asko zailtzen duen faktoreetako bat da (20). Adinaz gain, garrantzitsua da ezagutzea haur edo nerabe bakoitza garapen kognitiboaren zer fasetan aurkitzen den $(2,9,12,14,16,19,22,23)$. Teoria kognitibo guztietatik, ezagunenetakoa J. Piaget psikologoaren teoria da (12). Piagetek, haurren garapen kognitiboa, 4 alditan banatu eta aldi bakoitzean adinaren arabera haurrak duen logika azaldu zuen $(9,14,16,22,24)$.

- Zentzumenen eta mugimenduen aldia (0-2 urte): Hizkuntzaren edota mintzairaren aurreko aldia da. Lehen hilabeteetan haurrak ez du bere buruaren eta inguruaren kontzientziarik, baina zentzumenen eta mugimenduen bidez mundua ezagutzen doan neurrian, objektuen existentzia ulertzera iristen da aldi honen amaierarako $(14,24)$.

- Aldi honetan, haurrak ez du gaixotasun kontzeptua ulertzen $(14,16)$. Heriotza banaketa moduan bizi ohi du eta sentimenduak kexuen edota negarraren bidez azaleratzen ditu $(2,9$, 22).

- Operazio aurreko aldia (2-7 urte): Haurraren pentsamendua ikusi, entzun eta esperimentatzen duenaren araberakoa da (24). Pentsamendu magikoa nagusitzen da eta komunikatzeko orduan, funtzio sinbolikoa erabiltzen du $(14,24)$. Bestalde, Piageten arabera, aldi honetan haurraren jarrera egozentrikoa nagusitzen da, bere ikuspuntuak eta pentsamenduak soilik onartzen dituelarik (14).

- Gaixotasunari dagokionez, kanpoko fenomeno konkretu batek eragina dela azaltzen du. Bestalde, pentsamendu magikoaz baliatuz, gaixotasunaren arrazoia gertuan dauden objektuena eta pertsonena dela ere azal dezake (16).

- Heriotza, aldi batekoa, itzulgarria eta ez-unibertsala dela pentsatzen du. Aldi honetan, haurrak duen pentsamendu magikoaren eraginez, heriotza zigor moduan ulertzen du $(2,9$, 14, 22).

- Operazio zehatzen aldia (7-11 urte): Geroz eta pentsamendu logikoagoa nagusitzen da, pixkanaka helduen pentsamendura gerturatuz. Komunikazioari dagokionez, elkarrizketa bat ulertzeko gaitasuna agertzen da $(14,24)$. Aurreko aldian nabarmentzen zen egozentrismoa desagertuz doa eta haurra ikuspuntu desberdinak onartzeko gai da (24).

- Aldi honetan ere, gaixotasuna bi modutan ulertzen du. Alde batetik, gaixotasuna kanpoko norbaitek, kontaktu fisiko eta ekintza arriskutsu baten bidez eragindakoa dela ulertzen du. Bestetik, gaixotasuna guztiok barruan dugun zerbait dela pentsa dezake, baina gaixotasunaren azken eragilea kanpoko pertsona bat dela azaltzen du (16).

- Aurreko aldian nagusituriko pentsamendu magikoa desagertuz doan neurrian, heriotza itzulezina dela ulertuz doa haurra $(2,9,14,22)$. Horrekin batera, heriotzaren aurrean beldurra agertzen has daiteke (14).

- Operazio formalen aldia (11 urte-heldua): Nerabea gai da termino abstraktuen bidez pentsatzeko, sinboloak erabiltzeko eta ondorio logikoak ateratzeko. Aldi honetan, hipotesiak planteatzeko eta galdera teorikoak zein filosofikoak egiteko gaitasuna agertzen da $(14,24)$.

Gaixotasuna modu fisiologikoan ulertzen du, horren eragilea organo edo prozesu batek behar bezala ez funtzionatzea dela azalduz. Bestalde, modu psikofisiologikoan ere uler dezake, alor fisiologikoaz gain, jarrera psikologikoak ere gaixotasun-prozesuan eragina duela zehaztuz (16).

Heriotza, itzulezina, unibertsala eta saihestu ezin daitekeen errealitate bat dela ulertzen du $(2,9,10$, 14, 22). Hala ere, norberaren heriotza urruneko zerbaiten moduan ikusten da eta onarpenerako 
denbora bat behar izaten da. Aldi honetan, heriotza aurreko unearen eta gorputzaren kontrola galtzearen beldurra nagusitzen dira $(2,9,22)$.

Zainketa aringarri pediatrikoetan, Piagetek haurren garapen kognitiboaren inguruan azaldutako teoria tresna garrantzitsu bilakatzen da (24). Izan ere, ezinbestekoa da erizainak haurraren pentsatzeko prozesua ulertzen jakitea. Horrela, gaixo pediatriko bakoitzaren egoerara egokituz, eraginkorrak izango diren komunikazio-teknika edo jarduera egokiak aukeratu ahal izateko $(16,24)$.

\subsubsection{Komunikazio-teknikak}

Komunikazioa eraginkorra izan dadin, irekia izan behar du. Hau da, gaixotasun, tratamendu edota heriotzaren inguruko beldurrak, kezkak eta galderak, edota sentimendu eta pentsamendu positibo zein negatiboak, ahozko eta ez-ahozko komunikazioaren bidez libreki adierazteko aukera eskaini behar du. Komunikazio irekiaren bidez, haurrak edo nerabeak bere galdera guztiak seriotasunez hartuak eta zintzotasunez erantzunak direla sentitu behar du (12).

Gaixoak komunikatzeko prest dagoela adierazi arte itxaron behar da, bakoitzak behar duen denbora errespetatuz $(9,12,16)$. Gaixoak hitzez adieraz dezake komunikatzeko duen interesa, edota ez ahozko zeinuen bidez eskain dezake informazio bera (20).

Haurra edo nerabea izango da komunikazioaren erritmoa markatuko duena. Beraren galderak izango dira elkarrizketaren erritmoaren markatzaileak. Beraz, galderei zintzotasunez eta gezurrik esan gabe erantzungo zaien arren, ez da gomendatzen galdetzen duena baino haratago joatea $(9,12,25)$.

Osasun-profesionalaren zeregina izango da, elkarrizketa aurrera eramateko, gaixoa eroso sentitzen den konfiantzazko giroa sortzea. Horretarako, profesionalak bere burua aurkeztu eta gaixoari bere izenez deitzeak garrantzi berezia du (16). Horretaz gain, goxotasunez hitz egin eta jarrera enpatikoa azaltzea ere oinarrizkoa izango da komunikazio-prozesuan $(9,26)$. Jarrera enpatikoak bestearen tokian jarri eta, horrela, bere sentimenduak ulertzeko gaitasuna izateari egiten dio erreferentzia (26).

J. Amery medikuaren esanetan, haurrek eta nerabeek komunikatzeko 3 bide desberdin erabiltzen dituzte: ahozko komunikazioa, ahoz besteko komunikazioa eta jokoaren bidezko komunikazioa (27).

\section{a) Ahozko komunikazioa}

Haurrekin eta nerabeekin hitz egiteko orduan, hizkuntza eta terminologia erraza, argia eta ulergarria erabili behar da, gaixo bakoitzaren adinera eta egoerara egokituz $(9,12,27)$.

Balio terapeutikorik ez duten esaldi eginak saihestu behar dira $(9,14,20)$. Esaldi horiek erabiliz gero, haurrak edo nerabeak osasun-profesionalari ezer esan ez arren, erasana senti daiteke $(14,20)$.

Bestalde, jarrera paternalista ekidin behar da $(9,14,20,25)$. Osasun-profesionalak esandakoak garrantzi eta indar berezia du haur edo nerabearentzat, baita horren familiarentzat ere. Hori kontuan izanik, jarrera paternalista saihesteko, komenigarria da, "Egin beharko zenuke..."; "Zure onerako esaten dizut"... bezalako esaldien erabilera ekiditea (20).

Haurrekin eta nerabeekin mintzatzeko orduan, hitzez esaten denaz gain esateko moduak ere garrantzia du, paralinguistika kontuan hartzekoa delarik. Paralinguistikak hitzak esateko modua aztertzen du eta bere barnean sartzen dira tonua, tinbrea, abiadura, geldiuneak...(27).

\section{b) Ahoz besteko komunikazioa}

Ahoz besteko komunikazioa arreta berezia behar duen eta informazio ugari eskaintzen duen komunikazio-teknika da $(2,9,14,16,20)$. Komunikazio-teknika garrantzitsuena da, helarazten den eduki osoaren $\% 70$ hartzen baitu (16).

Era inkontzientean ematen da eta oso zaila izan ohi da kontrolatzea. Horregatik, ahozko komunikazioaren eta ahoz besteko komunikazioaren artean kontraesanak agertuz gero, ahoz besteko 
komunikazioari ematen zaio garrantzia, beraren bidez transmitituriko edukia baliagarriagotzat hartuz $(20,27)$.

Ahoz besteko komunikazioa adin guztietan da garrantzitsua. Baina haurra zenbat eta txikiagoa izan, orduan eta garrantzi handiagoa hartzen du komunikazio mota honek. Izan ere, haurrak mintzatzeko eta inguratzen duen mundua interpretatzeko erabiliko duen bide nagusia izango da (16).

Horrez gain, haurrak eta nerabeak ahoz besteko komunikazioaren irakurle bikainak dira. Osasunprofesionalen irribarre batek, eskuekin eginiko zeinuek, edota aurreraka pixka bat inklinatzeak esaterako, interesa eta goxotasuna transmititu ohi dute. Aldiz, besoak gurutzatuta mantentzeak hoztasuna eta jarrera itxia transmititzen ditu (27).

Aurrez aipatu bezala,ahoz besteko komunikazioa kontrolatzea zaila den arren, haurrekin eta nerabeekin komunikazioa hobetzen lagun dezaketen portaera batzuk ikastea posible dela ikusi da (20). Jarraian, osasun-profesionalek arreta jarri beharreko edota kontuan izan beharreko puntuak azalduko dira.

\section{b.1.) Entzute aktiboa}

Haurrekin eta nerabeekin komunikatzeko garaian, entzute aktiboa funtsezko tresna da $(2,9,12,16$, 20, 26).

Entzute aktiboa, solaskidearen adierazpen guztiak arretaz biltzean oinarritzen da. Hau da, ahozko komunikazioaren bidez azaldurikoaz gain, ez ahozko komunikazioaren bidez transmitituriko sentimenduak, beldurrak, beharrak... identifikatzean oinarritzen da $(9,20,26)$. Horrez gain, bere baitan sartzen dira elkarrizketa ez moztea, begietara begiratzea, entzuten zaiola adierazten duten seinaleak bidaltzea, ez epaitzea, isiltasun-tarteak errespetatzea eta hizketakideari erantzuteko denbora uztea (26).

Entzute aktiboa izango da osasun-profesionalari zer esan behar duen erabaki eta esan nahi duena adierazteko une egokia identifikatzen lagunduko dion tresna nagusia (20).

Modu aktiboan entzuten jakiteko, ezinbestekoa da alor hori pixkanaka landu eta geroz eta abilezia gehiago lortzea. Horrek, kontzientzia eta esfortzu handia eskatzen du osasun-profesionalen eguneroko lanean (20).

\section{b.2.) Isiltasun terapeutikoaren erabilera}

Egoera terminalean dauden haurrekin eta nerabeekin komunikatzeko, isiltasun-uneak tresna terapeutiko moduan erabiltzea medikuek zein erizainek landu beharreko eta garrantzia duen alor bat da $(9,20)$. Landu beharreko alorra dela esaten da, isiltasunak kasu askotan deserosotasuna eragin eta horren aurrean hitz egiteagatik hitz egiten hasteko joera agertu ohi delako (20).

Haur edo nerabe bati galdera bat egitean, esaterako, gogoan izan behar da denbora bat behar duela erantzuna pentsatzeko eta denbora hori normalean helduek igaro ohi dutena baino luzeagoa izaten dela. Beraz, galdera baten ondorenean sor daitekeen isiltasun-tartea normaltzat hartu eta segituan beste galdera bat egitea saihestu behar du osasun-profesionalak. Izan ere, isiltasun-tarte hori azkar moztu eta beste galdera batera igarotzeak gaixoarengandik lor daitekeen informazio interesgarria galtzea eragiten du (20).

Isiltasun-tartea asko luzatzen dela sumatzen den kasuetan, gertatzen ari dena esplizitu egitea da isiltasunarekin amaitzeko estrategia egokiena (20).

\section{b.3.) Postura}

Haurrak edo nerabeak osasun-profesionalaren begiak eta espresioa ikusi behar ditu une oro. Horretarako, biak altura berean egotea garrantzitsua da. Gainerakoan, gaixoa beldurtua senti daiteke eta horrek komunikazioa zailduko luke $(20,27)$. 
Ohean dauden eta altxa ezin duten gaixoen kasuan, esaterako, osasun-profesionala ohearen ertzean esertzeak gaixoa mugitzera behartu dezake elkarri begietara begiratzeko. Horregatik, gaixoa mugitzera behartu gabe begirada mantendu dezaketen posizio bat topatzea gomendatzen da (20).

\section{b.4.) Begirada}

Hitz egiten ari diren bitartean begietara begiratzea haurrek eta nerabeek baloratzen duten ekintza da. Osasun-profesionalak, begiradaren bidez, interesa eta entzuten ari dela adierazten dio gaixoari $(20,27)$.

Hala ere, begietara begira tinko egoteak gaixoa deseroso sentiaraz dezake. Horregatik, elkarrizketan zehar begirada une labur batez desbideratzeak haur edo nerabea lasai dezake, erabat obserbatua sentiaraztea saihestuz (20).

Horretaz gain, haurraren edo nerabearen begiradak ere informazio zabala eskain dezake, hala nola sufrimendua, mina edota ahoz adierazteko gai ez diren emozioak $(2,20)$. Begi-kontaktuaren gabeziak, aldiz, lotsa edota deserosotasuna adieraziko luke (20).

\section{b.5.) Gorputz-kontaktua}

Gorputz-kontaktuak erosotasuna, konfiantza, segurtasuna eta arreta transmititzen laguntzen du (20, 27). Ukimenaren bidez gaixoari adierazitako babesak, konfiantza-gradua eta sentimenduen adierazpena handitzen laguntzeaz gain, beldurrak kudeatzen laguntzen duela ikusi da, horien artean, heriotzaren inguruko beldurra. Horregatik, bizitzaren azken momentuetan eskua emateak edo laztan bat eskaintzeak garrantzi handia dute (27).

Gorputz-kontaktuaren erabilera haurrak edo nerabeak markatuko du, ahozko eta ahoz besteko komunikazioaren bidez bere erosotasun-maila adieraziz. Osasun-profesionalak ezin du pentsatu haur edo nerabe guztiek eskertuko dutela gorputz-kontaktuaren erabilera. Batzuek nahiago dute distantzia bat mantentzea eta osasun-profesionalak hori interpretatzeko gai izan behar du (20).

Hala ere, aipatzekoa da haurrek helduek baino hobeto toleratzen dutela kontaktu fisikoa eta horren behar handiagoa dutela, bereziki egoera terminalean dauden haurrek (27).

Nerabeen kasuan, sexualki garatzen ari diren aldia dela kontuan izanik, arreta gehiago jarri behar da. Gorputz-kontaktuaren interpretazio okerra egin dezakete. Beraz, nerabeak ezartzen dituen mugak ongi interpretatzeko, arreta berezia jarri beharko du osasun-profesionalak (20).

\section{d) Jokoaren bidezko komunikazioa}

Haurrak eta nerabeak ez dira miniaturazko helduak. Helduetan hitzez komunikatzeko joera nagusitzen den bezala, haurrek eta nerabeek joko eta jardueren bidez komunikatzeko joera izaten dute askotan $(28,29)$.

Haurren garapen kognitiboaren inguruan Piagetek azaldu zuenaren arabera, 11 urtetik aurrera garatzen da pentsamendu abstraktua. Helduek beren sentimendu, frustrazio edota arazoak modu batera edo bestera hitzez adieraztea lortzen badute ere, 11 urtetik beherako haurrei asko kostatzen zaie sentimendu edo emozioak hitzez adieraztea (28). Horregatik, kasu askotan jokoaren bidez adierazten dute gertatzen zaiena edo sentitzen dutena (12, 27-29).

Jokoak beren agresibitatea kanporatzen eta egoera onartzen laguntzen die egoera terminalean dauden haurrei eta nerabeei (27). Horregatik, musika, marrazkiak, jostailuak... inguruan izatea gomendatzen da, komunikazio-prozesuan laguntzeko $(20,27)$.

\subsection{Heriotzaren inguruko elkarrizketa}

Haurrekin eta nerabeekin heriotzaren inguruko elkarrizketa bat aurrera eramatea familiako kideei eta osasun-profesionalei gehien kostatzen zaien ekintzetako bat da $(10,30)$. 
Haurrek, ordea, heriotza helduek baino modu naturalagoan bizitzen dute eta horri buruz hitz egiteko aukera eskaintzen bazaie, aprobetxatu egiten dute $(30,31)$. Gertutasuna eta konfiantza transmititzen dien pertsona bat aurkitzen badute, heriotzaren inguruan modu irekian hitz egitera hel daitezke (20).

Nerabezaroa (OMEren arabera 11 urtetik aurrera), aldiz, etapa konplexuagoa da gaixoarentzat, familiarentzat eta baita osasun-profesionalentzat ere (10). Nerabeak ez dira haurrak, baina oraindik ez dira heldu izatera iritsi (25). 11 urtetik aurrera, ordea, heriotza helduen ikuspegi beretik ikusteko gai dira $(10,25)$. Aldi honetan heriotzaren onarpena zaila izaten da; izan ere, autonomia lortu eta gurasoengandik banantzeko prozesuaren hasierarekin batera heltzen da heriotza. Une horretan amets, ilusio eta proiektu guztiak apurtu eta berriro ere gurasoen beharrean aurkitzen da nerabea (30).

E. Kübler Ross medikuak azaldu zuen haurrek eta nerabeek beren heriotza gertu dagoela sumatu egiten dutela. Ingurukoek gaiaren inguruan ez hitz egitea erabaki arren, gaixoak denbora gutxi geratzen zaiola nabaritzen duela zehaztu zuen (31).

Bestalde, haurra edo nerabea bere heriotza gertu dagoela sentitzen doan neurrian, iraganean izandako bizipenak errepasatzen hasi ohi da eta bizipen horiekin lotura duten jarrera desberdinak adierazten ditu. Ohikoa izaten da, esaterako, iraganarekin lotutako ametsak izatea, txikiagoak zireneko ipuinak irakurtzeko eskatzea, postura fetalean jartzeko beharra izatea eta gurasoen besoetan denbora asko igarotzeko edota haiekin lo egiteko nahia azaltzea. Beraz, jarrera horiek kontuan hartzeak haurrak edo nerabeak heriotzaren inguruan duen kontzientzia baloratzen lagun diezaioke osasun-profesionalari $(30,31)$.

Haurrak zein nerabeak bizitzaren azken egunetan lagunduko dion norbaiten beharra du $(10,30,31)$. Oinarrizkoa da segurtasuna eta heriotzaren inguruko gaien aurrean naturaltasuna transmititzea, barneko sentimenduen adierazpena ahalbidetzeko (31).

Osasun-profesionalak baloratu behar du, familiako kideak gaixoarekin heriotzaren inguruan hitz egiteko prest dauden ala ez. Zuzeneko familiartekoen kasuan esaterako, ohikoa izaten da horrelako elkarrizketa bat izateko prestatuak ez egotea, oraindik egoera onartzeko prozesuan aurkitzen direlako. Kasu horietan, egoerari aurre egiteko prestatua dagoen eta gaixoarekin gertuko harremana duen beste kideren bat topatuz gero, berak har dezake eginkizun hori, osasun-profesionalekin elkarlanean $(10,30)$.

Egoera terminalean dagoen haurrak eta nerabeak heriotzaren inguruko galderak osasunprofesionalari egitea erabakiz gero, galdera hori nondik datorren, edota gai horrek gaixoari zer eragiten dion aztertu behar da $(30,31)$. Horretarako, galdera baten bidez erantzutea gomendatzen da, adibidez, "Gai horren inguruan hitz egin nahi al duzu?" edota "Zure gaixotasunaren egungo egoera ezagutzea gustatuko litzaizuke?" galderen erabilera izan daiteke aukera bat (31).

Gaixotasuna oso aurreratua dagoenean, gerta daiteke haurrak edo nerabeak bere heriotza nolakoa izango den galdetzea. Galdera horren aurrean, A. Navajas medikuak gomendatu zuen gaixoari begietara begiratu eta ondorengoa erantzutea: "Guztiok hilko garen arren, inork ez daki nola gertatuko den bakoitzaren heriotza. Hala ere, zuri ziurtatzen dizut, minik gabe, maite dituzun pertsonez inguratuta eta nahi baduzu zure etxean izango dela, zure jostailuekin, zure musikarekin" $(14,25)$.

Heriotza gerturatzen doan neurrian, gaixoarekin eta familiarekin komunikatzeko orduan kontuan izan beharreko beste puntu garrantzitsu bat espiritualtasuna da. OMEk zainketa aringarri pediatrikoen definizioan aipatu bezala, alor espirituala lantzea haurrei edo nerabeei eta horien familiei eskainiriko zainketen parte da. Alor horri arreta ez jartzea, sufrimendu psikologikoaren eragile izan daiteke (9).

Espiritualtasuna erlijioarekin lotzeko joera nabarmena den arren, hori ez da horrela (9). Pertsonak mundua ikusteko duen modua adierazten du espiritualtasunak eta bere barnean erlijioa sar daiteke 
edo ez (32). Espiritualtasunak pentsamenduak, balioak, ideiak eta jarrera desberdinak biltzen ditu eta horien bidez bakoitzak bere bizitzaren zentzua aurkitzen du $(9,32)$.

Espiritualtasuna haurrekin edo nerabeekin edota horien familiarekin lantzeko orduan, ohikoa izaten da "Zergatik gure seme-alabari?", "Zein da bizitzaren zentzua?"... bezalako galderak entzutea. Erantzun zaila duten galderak dira horiek eta osasun-profesionalak ez ditu gaixoak edota familiak galdera horien aurrean bilatzen dituen erantzunak (32). Beraz, osasun-profesionalak kontziente izan behar du eta onartu behar du, ez dakiela guztia eta badirela erantzunik ez duten galderak $(9,12,32)$. Hala ere, beharrezkoa da gaixoak eta bere familiak barnean dituzten galderak modu irekian formulatu eta kanporatzea. Hori egiteak lasaitasuna ematen die. Horregatik, osasun-profesionalak, hainbat galderaren erantzuna izan ez arren, galdera horiek entzun eta behar dutenerako presente agertzea lagungarria izango da gaixoarentzat eta familiarentzat $(9,32)$.

\subsection{Komunikazioa gaixoaren familiarekin}

Familia moduan ulertzen da haurrari edo nerabeari ongizate fisikoa, psikologikoa, espirituala eta soziala eskaintzen dion pertsona oro. Erlazio genetikoak alde batera utzita, haurrarekin edo nerabearekin maitasunezko eta ardurazko lotura duten pertsonak izaten dira (4).

Pediatriako gaixo terminalen kasuak badu berezitasunik. Izan ere, haurren eta nerabeen adina eta erabakitzeko gaitasuna kontuan izanik, beren zainketez arduratu eta kasu askotan berentzat erabakiak hartuko dituen heldu baten beharra dute (4).

Haurrak edo nerabeak gaixotasun terminal bat duela diagnostikatzeak inpaktu handia eragiten du familiako kideengan. Familiaren bizitzan aldaketa ugari gertatzen dira, haien helburu nagusia gaixoaren zainketetan zentratzea izaten delarik (33). Familiako kideen lana baldintzatu egiten da, bereziki zaintzaile nagusiaren kasuan, zeina gehienetan ama izaten den. Familiaren funtzionatzeko moduan eta antolaketa familiarrean aldaketak gertatzen dira eta, horrek, gurasoen banaketa eragiten du kasu batzuetan. Familiako kideen bizitza soziala eta aisialdia baldintzatzen dira eta zenbait kasutan osasun-arazoak agertzen dira (loaren nahasmendua, depresioa, antsietatea...), bereziki zaintzaile nagusiengan (14).

Haurraren edo nerabearen gurasoek, guraso izateaz gain, zaintzaile-eginkizuna hartzen dute kasu gehienetan, eta haurraren edo nerabearen onerako, erabaki gehienak beraiek hartuko dituztela espero izaten da (4).

Gurasoentzat, seme-alaba baten heriotza galera gogorrenetarikoa da eta kasu askotan gerta daitekeen injustizia handienetariko baten moduan bizi ohi dute $(2,9,31)$. Gurasoei kezka handia sortzen die haurra edo nerabea minez egon daitekeela edo sufri dezakeela pentsatzeak eta ohikoa izaten da kulpa-sentimendua agertzea $(2,8)$. Beraz, garrantzi handia izango du gurasoei babesa eskaini eta haien beldurren eta sentimenduen inguruan hitz egitea ahalbidetzeak $(2,9)$.

Entzute aktiboa ezinbestekoa da gurasoekin komunikatzeko orduan. Askotan gomendioen ordez, norbaitek beren beldurrak entzuteko beharra izaten baitute (9).

Gaixoaren senideen kasuan, aldiz, aipatzekoa da, gaur egungo gizartean, egoera terminalean dagoen haurraren edo nerabearen senideak alde batera uzteko joera nabarmentzen dela $(9,10,12,33)$. Askotan ez zaie gertatzen ari denaren inguruko azalpenik eskaintzen, baina nabaritu ohi dute gauzak ez doazela ondo. Informazio faltaren aurrean, ondorio propioak atera ohi dituzte eta ohikoa izaten $\mathrm{da}$, anai-arrebaren gaixotasuna, beraien jarrera txarraren ondorio dela pentsatzea $(9,10)$.

Horregatik, gaixoaren senideei egoeraren inguruko informazioa eskaini eta haiek ere zainketen parte egitea ezinbestekoa da $(9,12,25,33)$. Bakoitzak jaso nahi duen informazioa adinaren eta ulertzeko gaitasunaren arabera egokituz eskaintzeak heriotza-prozesura egokitzea, senideak agurtzea eta jarraian datorren dolu-prozesua errazten ditu (10). 
Familiako gainerako kideek ere (aitona-amonek, osaba-izebek, lagunek...) garrantzi handia dute, erantzukizunak partekatu eta babes emozionala eskaintzeko orduan (4).

Osasun-profesionalaren ezinbesteko zeregina izango da haur edo nerabearentzat garrantzitsuak diren familiako kideak identifikatzea. Horretaz gain, gaixoa bizitzaren azkeneko uneetan zaintzeko, praktikari dagokionez eta emozionalki, familia gai ote den baloratu eta zainketen pisu handiena eramango duen pertsona identifikatu beharko du (4).

Aurrez azaldurikoa kontuan izanik, zainketa aringarri pediatrikoetan funtzio garrantzitsua hartzen du osasun-profesionalaren eta familiaren arteko komunikazioak. Komunikazio egokiak laguntzen du gaixotasun-prozesuan zehar, agoniako unean, heriotzaren unean eta dolu-prozesuan zehar familiak pairatzen duen estresa, antsietatea eta depresioa gutxitzen (14).

Erizaina izanik familiarekin denbora gehien igarotzen duen profesionala, ohikoa izaten da familiaren galderei erantzun behar izatea. Familiak batzuetan kontraesana adierazten duten sentimenduak izaten ditu. Alde batetik, maite den pertsona baten galera gertuan ikusteak tristura eta pena sortu ohi ditu. Baina bestetik, sufrimenduarekin amaitzeko gogoa dutela adieraz dezakete. Horren aurrean, haurraren edo nerabearen heriotza azkartzeko zerbait egin daitekeen galde dezakete. Galdera edo eskaera hori dolu-prozesuaren parte dela ulertu behar da eta modu argian azaldu behar da osasunprofesionalen zeregina heriotza ahalik eta modu onenean gerta dadin beharrezko zainketak eskaintzea dela eta ez heriotza aurreratu edo atzeratzea (4).

Bestalde, ohikoa da familiak "Zenbat denbora geratzen zaio?" bezalako galderak egitea. Horrelako galderen erantzunik ez du osasun-profesionalak. Beraz, denbora-tarte bat esatea irreala izango da (4).

Osasun-profesionalak azpimarratu behar du guztien zeregina izango dela gaixoaren erosotasuna lortzea. Familia animatu behar du azken uneak gaixoarekin igarotzera, gaixoaren argitasun-uneak aprobetxatu, agurtu, airean dauden gaiak konpondu eta gaixoarekin igarotako momentu politak gogoratzera, zeina dolu-prozesurako lagungarri izango den (4).

Zainketa aringarri pediatrikoetan, familiari eskaini beharreko arreta eta haiekin izan beharreko komunikazioa ez da gaixotasunaren fase terminalean amaitzen, heriotzaren ondorenean ere arreta eskaintzean oinarritzen da (4). Gaixoa hil ondorenean, familiako kideek dituzten sentimendu eta emozioak azaleratzen lagundu behar zaie $(4,9)$.

Osasun-profesionalen zeregina izango da dolu aurreratuan behar diren zainketak eskaini eta dolu konplikatua prebenitzea (4). Osasun-profesionalen jarrerak eta gaixotasunaren fase terminalean zehar eskura dauden komunikazio-tekniken bidez haur edo nerabe, familia eta osasun-profesionalen arteko komunikazioa sustatzeak dolu konplikatuaren prebentzioan laguntzen duela ikusi da $(12,14$, 34).

\section{Eztabaida}

Lanaren helburu nagusiari erantzutea lortu den arren, gaiaren inguruko informazioa urria dela ikusi da.

Lan honen hasieran uste zenarekin eta errebisioan zehar aztertu diren erreferentzia askorekin bat, zainketa aringarri pediatrikoetan, egoera terminalean dauden gaixoei zainketak eskaintzeko orduan, komunikazioa funtsezko tresna da $(1,9,12,16-20)$.

Bestalde, aztertu diren erreferentzien gehiengoa ados agertu da gaixo pediatrikoekin komunikatzeak baduela berezitasunik azaltzeko orduan. Horrela, bada, komunikazioa haur eta nerabe bakoitzaren garapen kognitiboaren arabera egokitzearen garrantzia azpimarratzen dute $(2,9,12,14,16,19,22$, 23).

Artikulu gehienek orokorrean osasun-profesionalen inguruan hitz egiten dutela sumatu da. Artikulu gutxi batzuek, ordea, erizainari zuzeneko erreferentzia eginez, erizainaren komunikazio-gaitasunak, 
gaixoarekin eta haren familiarekin denbora gehien igarotzen duen profesionala izanik, garrantzi berezia hartzen duela azaltzen dute $(11,17,21)$. Horrela, bada, zainketa aringarri pediatrikoetan gaixoarekin zein familiarekin izan beharreko komunikazioa, erizainarekin uztartzen duen ikerketa gehiagoren beharra azaltzen dute artikulu batzuek $(10,17,21,35)$.

Formakuntza dela eta, ikerketa ugari ondorio berera iritsi dira eta erizainen artean formakuntza falta dagoela azaltzen dute. Ezinbestekotzat hartzen dute erizainei komunikazioaren inguruko etengabeko formakuntza eskaintzea $(17,21,29,35)$.

\section{Ondorioak}

Komunikazioa funtsezko tresna da erizainarentzat zainketa aringarri pediatrikoetan. Honen garrantzia justifikatua dagoen arren, praktikan gabezia ugari sumatzen diren alorra da. Hori horrela, oraindik ere zainketa aringarri pediatrikoen eta komunikazioaren alorrean ikertzeko asko dagoela ondorioztatu da.

Bestetik, ikusi da ahozko komunikazioak bere garrantzia duen arren, badirela kontuan hartu beharreko beste puntu batzuk. Horien arten, azpimarratzekoa da, ahoz besteko komunikazioak duen garrantzia. Gainera, jokoaren bidezko komunikaziori arreta eskaintzea ere garrantzitsua dela ondorioztatu da, haur eta nerabe guztiek erabiltzen duten komunikazio-bideetako bat baita.

Horrez gain, zainketa aringarri pediatrikoetan, osasun-profesionalen eta familiaren arteko komunikazioa gaixoarekin komunikatzea bezain garrantzitsua dela ikusi da. Familiak gaixotasunaren eta haren pronostikoaren inguruko informazio argia, sinplea eta ulergarria jasotzeko eskubidea du eta dolu-prozesuan arreta jasotzeko beharra.

Azkenik, osasun-profesionalei asko kosta arren, ondorioztatu da gaixoarekin eta haren familiarekin heriotzaren inguruko gaia lantzea garrantzitsua dela. Gaixoari, zalantzak eta beldurrak uxatzen eta, familiari, dolu patologikoaren prebentzioan lagunduko baitio.

\section{Mugak eta proposamenak}

Lan hau aurrera eramateko topatu den muga nagusia, gaiaren inguruko informazioaren urritasuna izan da. Artikulu eta ikerketa ugari baztertu dira, medikuen komunikazio-gaitasuna eta haiek landu beharreko komunikazio-teknikak jorratzea helburu zutelako. Horretaz gain, hautatu diren ikerketa gehienek osasun-profesionalen inguruan orokorrean dihardute. Horregatik, zainketa aringarri pediatrikoetan erizaina eta komunikazioa uztartzen dituzten ikerketen beharra ikusi da.

Bestalde, gaurko gizartean, heriotzak tabu izaten jarraitzen du eta hutsune handiak daude gaiaren inguruan hitz egiteko orduan. Horretatik, osasun-profesionalek eta bereziki erizainek, herritarrekin duten gertutasunagatik, ekimen desberdinen bidez heriotzaren gaia normalizatzeko bultzada bat ematea komenigarria ikusten da.

Amaitzeko, pediatriako gaixoen berezitasunak kontuan izanik, haiekin komunikatzeko erizainei formakuntza espezifikoa eskaintzea ezinbestekoa den arren, gure inguruan gaiaren inguruan formatzeko dauden aukerak urriak dira. Horregatik, formakuntza-saioak sustatu eta gaiari dagokion garrantzia ematea komeni dela ikusi da.

\section{Oharra}

Euskal Herriko Unibertsitateko (EHU) Erizaintzako Graduan eginiko gradu-amaierako lanean oinarrituta idatzitako artikulua da.

\section{Erreferentzia bibliografikoak}

1. Chaure I, Inarejos M. Enfermería pediátrica. Barcelona: Masson; 2004. 509-510 or.

2. Campos R, Paniagua S. El niño y adolescente al final de la vida. González P, Fundación Ramón 
Areces. Enfermería de la infancia y la adolescencia. Madrid: Ramón Areces; 2011. 361-380 or.

3. Sociedad Española de Cuidados Paliativos. Guía de Cuidados Paliativos [Internet]. Madrid: SECPAL; $2014 \quad$ [Kontsulta: 2018-12-07]. Eskuragarri: http://www.secpal.com//Documentos/Paginas/guiacp.pdf

4. Sánchez J. Guías para trabajar con el paciente moribundo. Situación de los últimos días. Astudillo W, Astigarraga I, Salinas A, Mendinueta C, Navajas A, D'Souza C, Jassal S. Medicina paliativa en niños y adolescentes. San Sebastián: Paliativos Sin Fronteras; 2015. 307-316 or.

5. Peláez $\mathrm{S}$, Casado P. Políticas sanitarias públicas: humanizando los cuidados paliativos pediátricos. Astudillo W, Astigarraga I, Salinas A, Mendinueta C, Navajas A, D'Souza C, Jassal S. Medicina paliativa en niños y adolescentes. San Sebastián: Paliativos Sin Fronteras; 2015. 111-120 or.

6. Gabriele G. Cuidados paliativos en Pediatría: perspectivas y tendencias. Astudillo W, Astigarraga I, Salinas A, Mendinueta C, Navajas A, D'Souza C, Jassal S. Medicina paliativa en niños y adolescentes. San Sebastián: Paliativos Sin Fronteras; 2015. 33-46 or.

7. Porras JA, Gutiérrez $C$, Palomares $M$, Navarro L, Navarro S. Acompañamiento y seguimiento de los niños con enfermedades neurológicas graves. Atención por parte de un equipo de cuidados paliativos pediátricos especializados [Internet]. Rev Neurol. 2018 Eka 5 [Kontsulta: 2019-01-31]; 66(S2):S47-51. Eskuragarri: https://doi.org/10.33588/rn.66S02.2018190

8. American Cancer Society. Cuando su hijo está recibiendo tratamiento contra el cáncer [Internet]. Atlanta: American Cancer Society; 2015 [Eguneratuta: 2015-11-11; Kontsulta: 2019-02-25]. Eskuragarri: https://www.cancer.org/es/tratamiento/los-ninos-y-el-cancer/cuando-su-hijo-tienecancer/durante-el-tratamiento/como-navegar-a-traves-del-sistema-de-atencion-medica.html

9. Villalba J. Afrontamiento de la muerte de un niño: Los cuidados pediátricos paliativos desde la Atención Primaria [Internet]. Rev Pediatr Aten Primaria. 2015 [Kontsulta: 2019-01-02]; 17(66):171-83. Eskuragarri: http://dx.doi.org/10.4321/S1139-76322015000300022

10. Del Rincón C, Martino R, Catá E, Montalvo G. Cuidados paliativos pediátricos: el afrontamiento de la muerte en el niño oncológico [Internet]. Psicooncología. 2008 [Kontsulta: 2019-02-01]; 5(23):425-37. Eskuragarri: https://revistas.ucm.es/index.php/PSIC/article/view/PSIC0808220425A

11. Melero A, García R. La comunicación en la relación terapéutica entre las competencias de enfermería: análisis en el contexto de oncopediatría [Internet]. ENE. 2016 Api [Kontsulta: 201901-02]; 10(1). Eskuragarri: http://eneenfermeria.org/ojs/index.php/ENE/article/view/599/comunicaciononco

12. Lascar E, Alizade MA, Rodríguez ME. Habilidades para la comunicación con niños y adolescentes que padecen cáncer. Cacciavillano W. Soporte clínico oncológico y cuidados paliativos en el paciente pediátrico [Internet]. Buenos Aires: Instituto Nacional de Cáncer; 2013 [Kontsulta: 201901-02]. 159-167 or. Eskuragarri: https://paliativossinfronteras.org/wpcontent/uploads/Soporte Pediatrico para el paciente Oncologico Febrero 2013.pdf

13. Real Academia Española. Diccionario de la Lengua Española [Internet]. Madrid: RAE; 2014 [Kontsulta: 2019-02-05]. Comunicación. Eskuragarri: https://dle.rae.es/?id=A58xn3c

14. Aguado J, Arcos L, Cía R, Fernández A, González A, Melguizo M, Ortega C, Paz M, Pérez JL, Quiroga E, Sanz R, Simón P. El final de la vida en la infancia y la adolescencia. Aspectos éticos y jurídicos en la atención sanitaria [Internet]. Sevilla: Junta de Andalucía. Consejería de salud; 2011 [Kontsulta: 2019-01-02]. 98-125 or. http://www.secpal.com//Documentos/Blog/archivo 304.pdf

15. 11/2016 Legea, uztailaren 8koa, bizitzaren amaierako prozesuan pertsonen eskubideak eta duintasuna ziurtatzeari buruzkoa. Euskal Herriko Agintaritzaren Aldizkaria [Internet], 134, 2016 Uzt 14. [Kontsulta: 2018-12-07]. Eskuragarri: https://www.euskadi.eus/y22bopv/eu/bopv2/datos/2016/07/1603138e.pdf

16. Floyd $M$, Dago $R$, Muñoz $G$. La comunicación con los niños $y$ adolescentes con enfermedad avanzada. Astudillo W, Astigarraga I, Salinas A, Mendinueta C, Navajas A, D'Souza C, Jassal S. Medicina paliativa en niños y adolescentes. San Sebastián: Paliativos Sin Fronteras; 2015. 77-87.

17. Montgomery K. Communication During Palliative Care and End of Life: Perceptions of Experienced Pediatric Oncology Nurses [Doktore-tesia]. Milwaukee: University of Wisconsin; 2013 [Kontsulta: 2019-01-02]. Eskuragarri: https://dc.uwm.edu/cgi/viewcontent.cgi?article=1443\&context=etd 
18. Weaver M, Heinze K, Kelly K, Wiener L, Casey R, Bell C, Wolfe J, Garee A, Watson A, Hinds P. Palliative Care as a Standard of Care in Pediatric Oncology [Internet]. Pediatr Blood Cancer. 2015 [Kontsulta: 2019-01-31]; 62(S5):S829-33. Eskuragarri: https://doi.org/10.1002/pbc.25695

19. Bennett K. Use your words. Healing communication with Children and teens in healthcare settings. Pediatr Nurs. 2016; 42(4):204-5.

20. Bild R, Gómez I. Acompañamiento creativo. Metodología para el cuidado del niño y adolescente con enfermedad terminal y su familia [Internet]. Valencia: Generalitat. Conselleria de Sanitat; 2008 [Kontsulta: 2019-01-02]. 59-75 or. http://www.secpal.com//Documentos/Blog/acompa\%C3\%B1amiento\%20creativo.pdf

21. Conner N, Uddin N. Predictors of Intention to Refer to Pediatric Palliative or Hospice Care [Internet]. Am J Hosp Palliat Care. 2015 (first on line) 2016 [Kontsulta: 2019-01-11]; 33(7):617-24. Eskuragarri: https://doi.org/10.1177/1049909115593062

22. Marcdante KJ, Kliegman RM. Nelson pediatría esencial. 7.ed. Barcelona: Elsevier; 2015. 7-9 or.

23. Ridley C, Helsby V, Crew K. Communicating with children and young people and their families. Webb L. Nursing: Communication skills in practice. Oxford: Oxford University Press; 2011. 244263 or.

24. González P. Crecimiento y desarrollo. Teorías sobre cómo comprenden el mundo niñas, niños y adolescentes. González P, Fundación Ramón Areces. Enfermería de la infancia y la adolescencia. Madrid: Ramón Areces; 2011. 41-52 or.

25. Gutiérrez Jl. Cuidado del adolescente con enfermedad terminal, ajuste familiar y soporte. Astudillo W, Astigarraga I, Salinas A, Mendinueta C, Navajas A, D’Souza C, Jassal S. Medicina paliativa en niños y adolescentes. San Sebastián: Paliativos Sin Fronteras; 2015. 89-96 or.

26. Castillo C, Lopéz MJ, Marcos C. Cuidados paliativos de enfermería en los niños y adolescentes. Astudillo W, Astigarraga I, Salinas A, Mendinueta C, Navajas A, D'Souza C, Jassal S. Medicina paliativa en niños y adolescentes. San Sebastián: Paliativos Sin Fronteras; 2015. 379-388 or.

27. Astudillo W, Acinas $P$, Mendinueta M, Bonilla AM. La comunicación, el juego y el dibujo en los niños. Astudillo W, Astigarraga I, Salinas A, Mendinueta C, Navajas A, D'Souza C, Jassal S. Medicina paliativa en niños y adolescentes. San Sebastián: Paliativos Sin Fronteras; 2015. 479494 or.

28. Landreth G. La terapia del juego. El arte de relacionarse jugando. Barcelona: Obelisco; 2018. 27-29r.

29. Akgun M, Mutlu A, Bilsel A. Experiences of Nursing students in caring for pediatric cancer patients [Internet]. Asian Pac J Cancer Prev. 2014 [Kontsulta: 2019-01-17]; 15(5):1955-1960. Eskuragarri: http://dx.doi.org/10.7314/APJCP.2014.15.5.1955

30. Carsí N. El niño ante la propia muerte. Bioet Debat. 2015; 21(76):13-6.

31. Carranza Z. El niño ante la muerte. Necesidades de la familia tras la muerte. Astudillo W, Astigarraga I, Salinas A, Mendinueta C, Navajas A, D'Souza C, Jassal S. Medicina paliativa en niños y adolescentes. San Sebastián: Paliativos Sin Fronteras; 2015. 621-630 or.

32. Edwards F. El dolor del alma en cuidados paliativos. Astudillo W, Astigarraga I, Salinas A, Mendinueta C, Navajas A, D'Souza C, Jassal S. Medicina paliativa en niños y adolescentes. San Sebastián: Paliativos Sin Fronteras; 2015. 559-571 or.

33. Salvador C, Salvador V, Segura A, Andrés M, Fernández JM, Niño OM, Reche E. Actualidad de los cuidados paliativos. Revisión de una situación poco estandarizada [Internet]. Rev Pediatr Aten Primaria. 2015 [Kontsulta: 2018-12-27]; 17(67):215-22(e215-22). Eskuragarri: http://dx.doi.org/10.4321/S1139-76322015000400017

34. Carreño S, Chaparro L, López R. Encontrar sentido para continuar viviendo el reto al perder un hijo por cáncer infantil: revisión integrativa [Internet]. Pers Bioét. 2017 [Kontsulta: 2019-01-11]; 21(1):46-61. Eskuragarri: http://dx.doi.org/10.5294/pebi.2017.21.1.4.

35. Navarro S. El desafío de la cronicidad compleja y la atención paliativa en pediatría [Internet]. An Pediatr. $2018 \quad$ [Kontsulta: 2018-12-27]; 88(1):1-2. $\quad$ Eskuragarri: https://doi.org/10.1016/i.anpedi.2017.11.010 